Perwira Journal of Economics and Business (PJEB)

E-ISSN : 2775-572X

Volume 1 Nomor 2

Agustus 2021

\title{
DAMPAK PERATURAN PEMERINTAH NOMOR 43 TAHUN 2014 TERHADAP PERANAN BADAN PERMUSYAWARATAN DESA DALAM PENYUSUNAN ANGGARAN PENDAPATAN DAN BELANJA DESA (STUDI PADA DESA DI KABUPATEN TEGAL)
}

\author{
Hesti Widianti', Muhamad Alfian² \\ ${ }^{1,2}$ Politeknik Harapan Bersama \\ Hesti28widianti@gmail.com
}

\begin{abstract}
ABSTRAK
Pemerintah desa merupakan bagian terdepan pada sistem pemerintahan daerah yang akan berhubungan dan bersentuhan langsung dengan masyarakat. Karena itu, sistem dan mekanisme penyelenggaraan pemerintahan daerah sangat didukung dan ditentukan oleh Pemerintah Desa dan Badan Permusyawaratan Desa (BPD) sebagai bagian dari Pemerintah Daerah. Struktur kelembagaan dan mekanisme kerja di semua tingkatan pemerintah, khususnya pemerintahan desa harus diarahkan untuk dapat menciptakan pemerintahan yang peka terhadap perkembangan dan perubahan yang terjadi dalam masyarakat. Penelitian ini bertujuan untuk mengetahui peranan BPD dalam penyusunan APBDes di Desa Kepunduhan, Kecamatan Kramat kabupaten Tegal. Berdasarkan Peraturan Pemerintah Nomor 43 Tahun 2014 Tentang Desa dan Fungsi dari BPD dalam menyusun Anggaran Desa. Dengan menggunakan metode penelitian kualitatif. Dari hasil penelitian dapat dilihat BPD masih memerlukan penguatan kapasitas kelembagaan.
\end{abstract}

Kata kunci: $B P D, A P B D e s$

Abstract: Village governments are the foremost of the regional government system that has a direct relation to the society. Therefore, the systems and mechanisms of regional governance are strongly supported and determined by village governments and district consultative body (BPD) as the part of a local governments. The institutional structure and the mechanism at all levels of government, especially the village governments that should be directed to create a government that are sensitive to developments and changes that taking place in the societies. This study aims to know the role of district consultative body (BPD) in the arrangement of $A P B D$ at the Kepunduhan Village, Kramat, Tegal District. According to government regulation number 432014 about the village government and the function of the BPD in creating a village budget with qualitative research methods. According to the report, BPD still needed reinforcement of institutional capacity

Keywords: BPD, APBDes 


\section{P ENDAHULUAN}

Pemerintah desa merupakan ujung tombak sistem pemerintahan daerah yang berhubungan langsung dengan masyarakat. Sistem dan mekanisme dari penyelenggaraan pemerintahan daerah sangat didukung dan dipengaruhi oleh Pemerintah Desa dan Badan Permusyawaratan Desa (BPD) sebagai bagian dari Pemerintah, dalam Peraturan Pemerintah Nomor 43 Tahun 2014 tentang Peraturan Pelaksanaan UndangUndang Nomor 6 Tahun 2014 tentang Desa berisi 91 halaman termasuk penjelasan. Peraturan Pelaksanaan UU Desa ini didalamnya mengatur tentang Penataan Desa, Kewenangan, Pemerintahan Desa, Tata Cara Penyusunan Peraturan Desa, Keuangan dan Kekayaan Desa, Pembangunan Desa dan Pembangunan Kawasan Perdesaan, Badan Usaha Milik Desa, Kerjasama Desa, Lembaga Kemasyarakatan Desa dan Lembaga Adat desa, dan Pembinaan dan Pengawasan Desa oleh Camat atau sebutan yang lainnya, Anggaran Pendapatan dan Belanja Desa (APBDes) adalah peraturan desa yang memuat sumber-sumber penerimaan dan alokasi pengeluaran desa dalam kurun waktu satu tahun. APBDes terdiri dari bagian pendapatan Desa, belanja Desa dan pembiayaan. Alokasi pengeluaran dalam APBDes meliputi belanja pembangunan dan pos pengeluaran rutin. Belanja pembangunan meliputi (1) pos sarana pemerintahan desa; (2) pos prasarana perhubungan; (3) pos prasarana pemasaran; (4) pos prasarana sosial. Belanja rutin meliputi (1) pos belanja pegawai; (2) pos belanja barang; (3) pos biaya pemeliharaan; (4) pos biaya perjalanan dinas; (5) pos belanja lain-lain; (6) pos pengeluaran tak terduga. Kelembagaan desa yang dimaksud pada penelitian ini adalah lembaga, pihak, atau institusi yang berada di desa yang berasal dari unsur eksekutif, legislatif, dan masyakat yang terlibat dalam penyusunan, pelaksanaan, dan pengawasan

Dalam proses pengamabilan keputusan di desa terdapat dua macam keputusan, Pertama keputusan - keputusan yang beraspek sosial, yang mengikat masyarakat secara sukarela, tanpa sanksi yang jelas, Kedua keputusankeputusan yang dibuat oleh lembagalembaga formal desa yang dibentuk untuk melakukan fungsi pengambilan keputusan. Untuk bentuk keputusan pertama, dapat dijumpai pada kehidupan sosial masyarakat desa, proses pengambilan keputusan dilakukan melalui proses persetujuan bersama, dimana sebelumnya alasan-alasan untuk pemilihan alternatif diuraikan terlebih dahulu oleh para tetua desa ataupun orang yang dianggap memiliki

Adapun pada bentuk kedua, keputusan keputusan yang berdasarkan pada prosedur yang telah disepakati bersama, seperti proses Musyawarah Pembangunan Desa (MUSBANGDES) yang dilakukan setiap setahun sekali dibalai desa. Proses pengambilan keputusan tersebut dilakukan oleh pihak - pihak secara hukum memang diberi fungsi untuk itu, yang kemudian disebut dengan peraturan desa (PerDes). Peraturan Desa (PerDes) merupakan produk hukum tingkat desa yang ditetapkan oleh kepala desa dan badan permusyawaratan desa dalam rangka penyelenggaraan pemeritah desa.

Badan Perwakilan Desa (BPD) yang ada selama ini berubah namanya menjadi Badan Permusyawaratan Desa. BPD memiliki fungsi menetapkan peraturan desa bersama kepala desa, manampung dan menyalurkan aspirasi masyarakat, oleh karenanya BPD sebagai badan permusyawaratan yang berasal dari masyarakat desa, disamping menjalankan fungsinya sebagai jembatan penghubung antara kepala desa dengan masyarakat desa, juga harus menjalankan fungsi utamanya, yakni fungsi representasi.

Kabupaten Tegal merupakan salah satu daerah kabupaten di Propinsi Jawa Tengah dengan Ibu Kota Slawi. Terletak antara

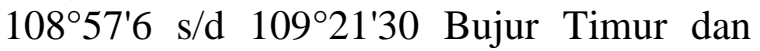
6050'41" s/d 7¹5 15'30" Lintang Selatan. Dengan keberadaan sebagai salah satu daerah yang melingkupi wilayah pesisir utara bagian barat Jawa Tengah, Kabupaten Tegal menempati posisi strategis di persilangan arus transportasi Semarang-Cirebon-Jakarta dan Jakarta-Tegal-Cilacap dengan fasilitas 
pelabuhan di Kota Tegal, Adapun batas-batas wilayah Kabupaten Tegal adalah sebelah Utara Kota Tegal dan Laut Jawa, sebelah Timur Kabupaten Pemalang, sebelah Barat Kabupaten Brebes, sebelah Selatan Kabupaten Brebes dan Kabupaten Banyumas. Luas wilayah Kabupaten Tegal 87.879 Ha, memiliki wilayah administrasi yang terdiri atas 18 kecamatan, 281 desa dan 6 kelurahan. Dasar hukum pembagian wilayah administrasi tersebut adalah Undang-Undang Nomor 13 Tahun 1950 tentang Pembentukan Daerah-Daerah Kabupaten dalam lingkungan Propinsi Djawa Tengah dengan 18 kecamatan.

Dari hasil observasi awal menunjukan bahwa peranan kelembagaan desa dalam menyusun APBDes sebagian sudah berjalan sesuai harapan, namun masih terdapat hambatan dan kendala di lapangan. Peran dominan terdapat pada kepala desa, terutama dalam penyusunan APBDes. Beberapa tokoh masyarakat yang masuk dalam keanggotaan BPD masih merasa belum dilibatkan secara maksimal dalam penyusunan APBDes tersebut, padahal menurut mereka penyusunan APBDes sangatlah penting dalam pembangunan desa bagi kesejahteraan rakyat, selain itu adanya keterbatasan sumber daya manusia yang mempunyai pemahaman keilmuan dibidang pengelolaan keuangan Desa sehingga sering kali terlambat dalam pelaporan, dalam hal ini peran pemerintah kabupaten Tegal sangat diperlukan seperti adanya sosialisasi dan pelatihan perangkat Desa

Kajian penelitian diarahkan pada peranan BPD dalam menyusun dan APBDes di Era Otonomi Daerah. Permasalahan yang muncul adalah, BPD tidak melaksanakan fungsinya secara optimal untuk mewujudkan APBDes yang partisipatif, forum BPD menjadi elit desa semata dimana saluran aspirasi masyarakat terhambat terutama dalam penyusuanan APBDes yang memerlukan pembahasan secara partisipatif begitu juga pengawasannya sebagaimana salah satu tugas BPD menggali, menampung, menghimpun, merumuskan dan menyalurkan aspirasi masyarakat.

\section{KAJIAN LITERATUR}

\section{Konsep Peranan}

Kata peranan ini sebenarnya menunjukan pada aktifitas yang dilakukan seseorang untuk melakukan sesuatu dalam kelompok masyarakat. Dengan demikian kata peran berarti sesuatu berupa orang, benda atau barang yang memegang pimpinan atau karena suatu hal atau peristiwa.

\section{Badan Permusyawaratan Desa}

Badan Permusyawaratan Desa merupakan lembaga sebagai perwujudan demokrasi dalam penyelenggaraan pemerintahan desa sebagai unsur penyelenggara pemerintahan desa. Badan Permusyawaratan Desa berfungsi menetapkan peraturan desa bersama dengan kepala desa guna menampung dan menyalurkan aspirasi masyarakat. BPD berkedudukan sebagai unsur penyelenggara pemerintahan desa. Anggota BPD adalah wakil dari penduduk desa bersangkutan berdasarkan keterwakilan wilayah yang ditetapkan dengan cara musyawarah dan mufakat.

BPD berfungsi menetapkan peraturan desa bersama Kepala Desa, menampung dan menyalurkan aspirasi masyarakat. Wewenang BPD yaitu.
a. Membahas rancangan peraturan desa bersama kepala desa;
b. Melaksanakan pengawasan terhadap pelaksanaan peraturan desa dan peraturan kepala desa;
c. Mengusulkan pengangkatan dan pemberhentian kepala desa;
d. Membentuk panitia pemilihan kepala desa;
e. Menggali,menampung, menghimpun, merumuskan dan menyalurkan aspirasi masyarakat; dan
f. Menyusun tata tertib BPD.

\section{APBDesa}

Pengelolaan Keuangan Desa adalah keseluruhan kegiatan yang meliputi perencanaan, penganggaran, penatausahaan, pelaporan, pertanggung-jawaban dan pengawasan keuangan desa. Anggaran 
Pendapatan dan Belanja Desa, selanjutnya disingkat APBDesa adalah rencana keuangan tahunan pemerintahan desa yang dibahas dan disetujui bersama oleh pemerintah desa dan Badan Permusyawaratan Desa, dan ditetapkan dengan peraturan desa. Pembiayaan desa, meliputi semua penerimaan yang perlu dibayar kembali dan/atau pengeluaran yang akan diterima kembali, baik pada tahun anggaran yang bersangkutan maupun pada tahun-tahun anggaran berikutnya.

\section{METODE PENELITIAN \\ Jenis Penelitian}

Penelitian ini merupakan penelitian kualitatif. Moleong (2007: 6) yang memaknai penelitian kualitatif sebagai penelitian yang bertujuan untuk memahami fenomena yang dialami oleh subjek penelitian. Baik digunakan untuk meneliti hal-hal yang berkaitan dengan penelitian perilaku, sikap, motivasi, persepsi dan tindakan subjek. Dengan kata lain, jenis penelitian tersebut, tidak bisa menggunakan metode kuantitatif. .

Penelitian ini merupakan penelitian kualitatif. Bogdan dan Taylor menjelaskan bahwa metodologi penelitian kualitatif merupakan prosedur penelitian yang menghasilkan data deskriptif berupa katakata tertulis atau lisan dari orang-orang dan perilaku yang dapat diamati.4 Dalam penelitian kualitatif seorang peneliti berbicara langsung dan mengobservasi beberapa orang, dan melakukan interaksi selama beberapa bulan untuk mempelajari latar, kebiasaan, perilaku dan cirri-ciri fisik dan mental orang yang diteliti. Bogdan dan Biklen mengemukakan bahwa karakteristik dari penelitian kualitatif adalah: (1) alamiah, (2) data bersifat deskriptif bukan angkaangka, (3) analisis data dengan induktif, dan (4) makna sangat penting dalam penelitian kualitatif.

Fokus penelitiannya adalah studi peranan BPD dalam penyusunan Anggaran Pendapatan dan Belanja Desa (APBDes) di Desa Kepunduhan di Kabupaten Tegal

\section{Informan}

Informan (narasumber) penelitian adalah seseorang yang memiliki informasi mengenai objek penelitian tersebut. Informan dalam penelitian ini yaitu berasal dari dari wawancara langsung yang disebut sebagai narasumber. Dalam penelitian ini menentukan informan dengan menggunakan teknik purposive, yaitu dipilih dengan pertimbangan dan tujuan tertentu, yang benar-benar menguasai suatu objek yang peneliti teliti.(Menurut Denzin dalam Patton (2006: 99)

\section{Pengumpulan Data \\ a. Jenis Data}

Data yang dikumpulkan terdiri atas data primer dan data skunder. Data primer merupakan data yang langsung dikumpulkan pada saat melaksanakan penelitian di lapangan berupa rekaman wawancara, pengamatan langsung melalui komunikasi yang tidak secara langsung tentang pokok masalah. Sedangkan data sekunder adalah data yang merupakan hasil pengumpulan orang atau instansi dalam bentuk publikasi, laporan, dokumen, dan buku-buku lainnya yang berkaitan dengan penelitian ini.

\section{b. Pengumpulan Data}

Pengumpulan data yang dilakukan dalam penelitian ini sebagaimana dikemukakan Moleong (2006:198) adalah sebagai berikut.

1. Wawancara semi struktur

Jenis wawancara ini sudah termasuk dalam kategori in-depth interview, dimana dalam pelaksanaannya lebih bebas dibandingkan dengan wawancara terstruktur.

2. Observasi.

Observasi atau biasa dikenal dengan pengamatan adalah salah satu metode untuk melihat bagaimana suatu peristiwa, kejadian, hal-hal tertentu terjadi. Observasi menyajikan gambaran rinci tentang aktivitas program, proses dan peserta.

\section{HASIL PENELITIAN DAN PEMBAHASAN}




\section{Legalitas Badan Permusyawaratan Desa pada Pemerintah Desa}

Perubahan kelembagaan tersebut tidak hanya berdampak positif dalam pelaksanaan Pemerintahan Desa, tetapi juga dalam pemantauan di Desa sedangkan, sering memunculkan efek negatif dalam hubungan antarlembaga di desa dan bahkan terhadap masyarakat secara umum. Tingkat pemahaman aparatur desa dan anggota BPD dalam menjalankan mekanisme demokrasi di tingkat desa juga menjadi penyebab munculnya berbagai konflik dalam hubungan antar-lembaga di desa.

Sebagai Daerah Otonom daerah mempunyai kewenangan yang luas dan tanggung jawab yang besar untuk melaksanakan kepentingan masyarakat berdasarkan prinsip-prinsip keterbukaan, partisipasi masyarakat dan pertanggungjawaban kepada masyarakat. Badan Permusyawaratan Desa berkedudukan sejajar dan menjadi mitra kerja Pemerintahan Desa diharapkan dapat menjalankan fungsinya sebagai lembaga yang mengawasi jalannya Pemerintahan Desa. Oleh karena itu, pengaturan tentang Pemerintahan Desa dituangkan dalam peraturan daerah sebagaimana diamanatkan dalam Undangundang Nomor 6 Tahun 2014 tentang Desa.

Kewenangan BPD berdasarkan Peraturan Pemerintah Nomor 43 Tahun 2014 adalah:

a. membahas rancangan peraturan Desa bersama kepala Desa.

b. melaksanakan pengawasan terhadap pelaksanaan peraturan Desa dan peraturan kepala Desa.

c. mengusulkan pengangkatan dan pemberhentian kepala Desa.

d. membentuk panitia pemilihan kepala Desa.

e. menggali, menampung, menghimpun, merumuskan dan menyalurkan aspirasi masyarakat: danmenyusun tata tertib BPD.

Hak BPD seperti yang tercantum dalam Peraturan Pemerintah Nomor 43 Tahun 2014 adalah meminta keterangan kepada Pemerintah Desa dan menyatakan pendapat. BPD dalam pemerintahan desa berkedudukan sebagai lembaga legislatif, yaitu sebagai badan untuk tempat berdiskusi bagi para wakil masyarakat desa yang ada.

Berdasarkan kedudukannya , BPD memiliki tugastugas pokok untuk.

1. Merumuskan peraturan-peraturan (legislating function) yang dibutuhkan oleh Desa, yang selanjutnya disahkan dengan Surat Keputusan Kepala Desa.

2. Bersama Kepala Desa membuat Anggaran Penerimaan dan Pengeluaran Keuangan Desa (APBDes) (budgetting function).

3. Mengawasi eksekutif desa (Kepala Desa beserta Perangkatnya) dalam pelaksanaan pemerintahan sehari-hari (controlling function).

2. Proses Perancangan Anggaran Penerimaan dan Belanja Desa (APBDes)

Perencanaan pembangunan desa disusun secara berjangka meliputi.

(1) Rencana pembangunan jangka menengah desa yang selanjutnya disebut RPJMD untuk jangka waktu 5 (lima) tahun.

(2) Rencana kerja pembangunan desa, selanjutnya disebut RKP-Desa, merupakan penjabaran dari RPJMD untuk jangka waktu 1 (satu) tahun.

\section{a. Anggaran Penerimaan dan Belanja} Desa (APBDes)

Struktur APBDes dalam Anggaran Pendapatan dan Belanja Desa (APBDes) terdiri dari: a. Pendapatan Desa, b. Belanja Desa, dan c. Pembiayaan Desa. Pembiayaan desa, terdiri dari semua penerimaan yang perlu dibayar kembali dan/atau pengeluaran yang akan diterima kembali, baik pada tahun anggaran yang bersangkutan maupun pada tahun anggaran berikutnya.

Penatausahaan Pengeluaran wajib dilakukan oleh Bendahara Desa. Dokumen penatausahaan pengeluaran diharuskan sesuai pada Peraturan Desa tentang APBDes atau Peraturan Desa 
tentang Perubahan APBDes melalui pengajuan surat permintaan pembayaran .

\section{b. Alokasi Dana Desa}

Alokasi Dana Desa berasal dari APBD Kabupaten/Kota yang bersumber dari bagian dana perimbangan keuangan pusat dan daerah yang diterima oleh kabupaten/Kota untuk Desa paling sedikit $10 \%$ (sepuluh persen). Pelaksanaan kegiatan-kegiatan yang pembiayaannya bersumber dari ADD dalam APBDesa, sepenuhnya dilaksanakan oleh Tim Pelaksana Desa dengan mengacu pada Peraturan Bupati/Walikota. Penggunaan Anggaran Alokasi Dana Desa adalah sebesar 30\% (tigapuluh persen) untuk belanja aparatur dan operasional pemerintah desa, sebesar $70 \%$ (tujuh puluh persen) untuk biaya pemberdayaan masyarakat. BPD Terlibat dalam Segenap Proses Penyusunan APBDes.

Pelaksanaan kegiatan-kegiatan yang pembiayaannya bersumber dari ADD dalam APBDesa, sepenuhnya dilaksanakan oleh Tim Pelaksana Desa dengan mengacu pada Peraturan Bupati/Walikota.

Penggunaan

Anggaran Alokasi Dana Desa adalah sebesar 30\% (tiga puluh persen) untuk belanja aparatur dan operasional pemerintah desa, sebesar 70\% (tujuh puluh persen) untuk biaya pemberdayaan masyarakat.

\section{c. BPD Terlibat dalam Segenap Proses Penyusunan APBDes}

Desa

Kepunduhan menyelenggarakan Musrenbang Desa ditahun 2016, yang dihadiri oleh Kepala Dusun, organisasi masyarakat, BPD, Palmas, tokoh masyarakat, tokoh pemuda dan PKK, tokoh adat. Pemerintah Desa Kepunduhan berusaha untuk dapat melibatkan masyarakat dalam hal ini BPD sebagai penyalur aspirasi masyarakt desa dalam setiap tahap proses perencanaan pembangunan tahun ini. Kepala Desa menjelaskan bahwa proses perencanaan pembangunan yang diselenggarakan selama sehari sedapat mungkin bisa melibatkan masyarakat secara keseluruhan, namun karena kesibukan dan keterbatasan ruang maka tidak seluruhnya diundang, namun aspirasi mereka sudah ditampung dalam list daftar prioritas kegiatan lingkungan.

Hampir semua dusun di Desa Kepunduhan mengusulkan kegiatan yang sama, yang membedakan hanya lokasi kegiatannya saja. Berikut daftar masalah dan kebutuhan masyarakat yang diusulkan oleh perwakilan masyarakat dusun yang ada di Desa Kepunduhan yakni perbaikan Jalan, pengaspalan jalan, pembangunan jalan setapak, pembangunan Jalan kebun, pembangunan Posyandu, perbaikan saluran air. Fenomena usulan dalam musrenbang desa didominasi kegiatan fisik.

Sesudah Musrenbang, sebagaimana yang telah diatur bahwa rancangan rencana pembangunan desa akan dimasukan ke dalam Anggaran Pembangunan dan Belanja Desa, dimana anggaran ADD akan masuk didalamnya sebagai salah satu sumber APBDes. Peran masyarakat dapat terlihat dalam peran dari tokoh masyarakat dalam hal partisipasinya dalam penyusunan ADD yang melalui proses musyawarah pembangunan desa, kemudian penyusunan APBDes. Keterlibatan tokoh masyarakat sangat penting untuk menghasilkan rencana pembangunan dan APBDes selanjutnya menjadi ADD yang tepat sasaran.

Masalah dan kebutuhan yang diusulkan di tingkat desa tidak seluruhnya berasal dari kegiatan 
pengusulan program yang dilakukan di tingkat lingkungan, bahkan untuk beberapa ide usulan yang dirumuskan digali oleh elit desa seperti Kepala Desa dan perangkatnya. Penyebab lainnya adalah bahwa keterbatasan pemahaman masyarakat atau tokoh masyarakat tentang perencanaan partisipatif menghambat pelaksanaan pengusulan program juga menghambat perencanaan pembangunan.

Terdapat kesulitan dalam mengumpulkan masyarakat untuk merumuskan masalah dan kebutuhan pembangunan desa, tidak sedikit dari mereka yang tidak mengetahui tujuan dari kegiatan tersebut. Diperlukan pemberian pemahaman kepada masyarakat, supaya sesuai dengan tujuan perencanan partisipatif yaitu bersamasama merumuskan dan memutuskan langkah-langkah pembangunan yang perlu dilakukan untuk membangun desa atau wilayah mereka, yang kedua, menghasilkan suatu rencana pembangunan yang komprehensif yang merupakan hasil kesepakatan bersama.

Pentingnya kegiatan mengidentifikasi masalah dan kebutuhan masyarakat sebagai langkah penting dalam pembangunan yang mendekati kebutuhan masyarakat adalah mengidentifikasi masalah dan kebutuhan masyarakat tersebut. Tidak semua lingkungan melakukan penjaringan masalah dan kebutuhan masyarakat serta tidak semua masyarakat dilibatkan dalam kegiatan pengusulan program untuk mengetahui dan menggali masalah dan kebutuhan masyarakat dalam memenuhi prinsip kesesuaian antara rencana pembangunan dengan masalah dan kebutuhan masyarakat. Sehingga apabila tidak ada kesesuaian antara rencana dengan masalah dan kebutuhan masyarakat itu merupakan hal yang wajar.

\section{d. BPD Berperan Dalam Proses Penyusunan APBDes Mewujudkan APBDes Akuntabel dan Partisipatif.}

Melihat peranan BPD dalam perencanaan anggaran desa yang partisipatif dan akuntabel, akan dilihat pada tahapan-tahapannya. Peran masyarakat dapat terlihat dalam peran dari tokoh masyarakat dalam hal partisipasinya dalam penusunan APBDes dan ADD yang melalui proses musyawarah pembangunan desa, kemudian penyusunan APBDes. Keterlibatan tokoh masyarakat sangat penting untuk menghasilkan rencana pembangunan dan APBDes selanjutnya menjadi ADD yang tepat sasaran. Persoalannya dalam hal niat baik pemerintah desa untuk antusias melibatkan masyarakat melalui tokoh masyarakatnya. Kemudian kemampuan Sumber Daya Manusianya dalam berpartisipasi pada perencanaan pembangunan. Menjadikan Alokasi Dana Desa (APBDes dan ADD) yang partisipatif.

Dalam rangka penyelenggaraan pemerintahan desa disusun perencanaan pembangungan desa sebagai satu kesatuan dalam sistem perencanaan pembangunan daerah kabupaten/kota. Perencanaan pembangunan desa disusun secara partisipatif oleh pemerintahan desa sesuai dengan kewenangannya. Dalam menyusun perencanaan pembangunan desa wajib melibatkan lembaga kemasyarakatan desa.

ADD merupakan salah satu sumber pendapatan desa yang penggunaannya terintegrasi dengan Anggaran Pendapatan dan Belanja Desa (APBDes). Oleh karena itu perencanaan program dan kegiatannya disusun melalui forum Musyawarah Pembangunan

Perencanaan Desa 
(Musrenbangdes). Musrenbangdes tersebut merupakan forum pembahasan usulan rencana kegiatan pembangunan di tingkat desa yang berpedoman pada prinsip-prinsip Perencanaan Pembangunan Partisipasi Masyarakat Desa (P3MD). Prinsip tersebut mengharuskan keterlibatan masyarakat dalam pengambilan keputusan dan menentukan pembangunan yang akan dilaksanakan khususnya yang berlokasi di desa yang bersangkutan, sehingga benar-benar dapat merespon kebutuhan/aspirasi yang berkembang.

Dari hasil musyawarah yang dilaksanakan oleh masyarakat desa, maka alokasi penggunaan dana ADD yang telah diusulkan dari masingmasing desa yang digunakan untuk operasional pemerintah desa dan kegiatan pemberdayaan masyarakat secara terperinci dapat dilihat dalam data rekapitulasi hasil musrenbang yang telah disepakati. Hasil perencanaan tersebut akan menjadi pedoman penyelenggaraan pemerintahan desa dan pembangunan desa dalam kurun waktu satu tahun, di samping kegiatankegiatan lain yang sumber dananya di luar ADD. Dengan demikian perencanaan yang disepakati juga harus transparan, dapat diketahui oleh seluruh lapisan masyarakat yang nantinya dapat dipertanggungjawabkan.

e. Penelitian lebih dalam mengenai BPD dalam Penyusunan APBDes

Tokoh masyarakat di Desa kepunduhan berupa Tokoh pemuda, Tokoh Agama, Aktivis LSM, Pensiunan Guru, Para mantan kepala desa, Para mantan Perangkat Desa, Lembaga Adat, Pengurus ranting parpol. Mereka senantiasa berada dalam segala bidang kemasyarakat di desa. Partisipasi politiknya dalam desa kebanyakan disalurkan melalui lembaga kemasyarakatan BPD atau Badan Perwakilan Desa.
Eksekutif yang terdiri dari pemerintah desa, sekdes, kaur-kaur, kepala lingkungan, dan lembaga kemasyarakat desa melakukan evaluasi terhadap pelaksanaan APBDes tahun lalu dan melakukan proyeksi untuk penyusunan APBDes tahun mendatang. Sedangkan BPD melakukan kegiatan yang sama yakni melakukan evaluasi terhadap hasil pengawasan APBDes tahun lalu dan melakukan proyeksi untuk APBDes tahun mendatang.

Dalam rangka penyelenggaraan pemerintahan desa disusun perencanaan pembangungan desa sebagai satu kesatuan dalam sistem perencanaan pembangunan daerah kabupaten/kota. Perencanaan pembangunan desa disusun secara partisipatif oleh pemerintahan desa sesuai dengan kewenangannya. Dalam menyusun perencanaan pembangunan desa wajib melibatkan lembaga kemasyarakatan desa.

\section{SIMPULAN DAN SARAN}

\section{Simpulan}

a. Tugas dan kewajiban BPD menurut PP no 43 tahun 2014 dalam penyusunan anggaran pendapatan dan Belanja Desa (APBDes) di Kabupaten Tegal

\begin{tabular}{|l|l|l|}
\hline $\begin{array}{l}\text { PP 43 } \\
\text { TAHUN } \\
\text { 2014 }\end{array}$ & $\begin{array}{l}\text { PENERA } \\
\text { PAN }\end{array}$ & $\begin{array}{l}\text { KESIMPU } \\
\text { LAN }\end{array}$ \\
\hline $\begin{array}{l}\text { Berdasarka } \\
\text { n }\end{array}$ & $\begin{array}{l}\text { Keterlibat } \\
\text { an BPD }\end{array}$ & Sesuai \\
kedudukann & dalam & \\
ya B BPD & Proses \\
memiliki & Penyusuna \\
tugastugas & n APBDes \\
pokok & Contohny & \\
untuk. & a & \\
a. Merumu & keikutsert \\
skan & aan di \\
peratura & Musrenba \\
n- & ng Desa, \\
peratura & BPD & \\
n & Berperan & \\
$\quad$ legislati & Dalam & \\
$n g$ & Proses & \\
\hline
\end{tabular}




\begin{tabular}{|l|l|l|}
\hline function) & Penyusuna \\
yang & n APBDes & \\
dibutuhk & Mewujudk & \\
an oleh & an & \\
Desa, & APBDes & \\
yang & Akuntabel & \\
selanjutn & dan & \\
ya & Partisipati & \\
disahkan & f. \\
dengan & \\
Surat & \\
Keputus & \\
an & \\
Kepala & \\
Desa. & \\
Bersama & \\
Kepala & \\
Desa & \\
membuat & \\
Anggara & \\
n & \\
Penerim & \\
aan dan & \\
Pengelua & \\
ran & \\
Keuanga & \\
n Desa & \\
(APBDe & \\
s) & \\
(budgetti & \\
ng & \\
function) & \\
ing & \\
function) & \\
Mengaw & \\
asi & \\
eksekutif & \\
desa & \\
(Kepala & \\
Desa & \\
beserta & \\
Perangka & \\
tnya) & \\
dalam & \\
aan & \\
\end{tabular}

b. Faktor yang mempengaruhi pelaksanaan peran BPD dalam penyusunan anggaran pendapatan dan Belanja Desa (APBDes)

\begin{tabular}{|c|c|c|}
\hline $\begin{array}{l}\text { PP } 43 \\
\text { TAHUN } \\
2014\end{array}$ & $\begin{array}{l}\text { PENERA } \\
\text { PAN }\end{array}$ & $\begin{array}{l}\text { KESIMP } \\
\text { ULAN }\end{array}$ \\
\hline $\begin{array}{l}\text { Peran } \\
\text { Perencan } \\
\text { aan dan } \\
\text { Pembang } \\
\text { unan } \\
\text { Desa } \\
\text { Perencan } \\
\text { aan } \\
\text { pembang } \\
\text { unan desa } \\
\text { disusun } \\
\text { secara } \\
\text { partisipati } \\
\text { f oleh } \\
\text { pemerinta } \\
\text { han desa } \\
\text { sesuai } \\
\text { dengan } \\
\text { kewenang } \\
\text { annya. } \\
\text { Dalam } \\
\text { menyusu } \\
\text { n perencana } \\
\text { an pembang } \\
\text { unan desa } \\
\text { wajib } \\
\text { melibatka } \\
\text { n lembaga } \\
\text { kemasyar } \\
\text { akatan } \\
\text { desa. }\end{array}$ & $\begin{array}{l}\text { Peranan } \\
\text { kelembag } \\
\text { aan desa } \\
\text { Kepundu } \\
\text { han dalam } \\
\text { rangka } \\
\text { menyusun } \\
\text { dan } \\
\text { melaksan } \\
\text { akan } \\
\text { APBDes } \\
\text { sudah } \\
\text { cukup } \\
\text { baik. } \\
\text { Kendala } \\
\text { pelaksana } \\
\text { an peran } \\
\text { kelembag } \\
\text { aan desa } \\
\text { di desa } \\
\text { Kepundu } \\
\text { han dalam } \\
\text { rangka } \\
\text { penyeleng } \\
\text { garaan } \\
\text { pemerinta } \\
\text { han desa } \\
\text { seperti } \\
\text { menyusun } \\
\text { dan } \\
\text { melaksan } \\
\text { akan } \\
\text { APBDes. }\end{array}$ & $\begin{array}{l}\text { Sudah } \\
\text { cukup } \\
\text { baik } \\
\text { tetapi } \\
\text { perlu } \\
\text { adanya } \\
\text { sosialisai, } \\
\text { pelatihan } \\
\text { terkait } \\
\text { penyusun } \\
\text { an dan } \\
\text { pelaksana } \\
\text { an } \\
\text { APBdes }\end{array}$ \\
\hline
\end{tabular}

\section{Saran}

1. Bagi kepala desa dan BPD di Desa Kepunduhan, hendaknya menyadari peran, tugas, fungsi, dan posisi masingmasing. 
2. Strategi pengembangan peningkatan peranan kelembagaan desa yang perlu dilakukan di era otonomi daerah sekarang ini

3. Perlu penyempurnaan tahapan pelaksanaan perencanaan partisipatif agar dapat dilaksanakan secara simpel dan mudah dipahami.

\section{DAFTAR PUSTAKA}

Conyers, Diana, 1994, Perencanaan Sosial di Dunia Ketiga: Suatu Pengantar, Gadjah Mada University Press, Yogyakarta.

Kartasasmita, Ginanjar, 1997, Administrasi Pembangunan, LP3ES, Jakarta. Moleong, Lexy, 2006, Metodologi Penelitian Kualitatif , PT. Remaja Rosada Karya, Bandung.

Mubiyarto, 1984, Pembangunan Pedesaan, P3PK UGM, Yogyakarta. Mikkelsen, Britha, 2006, Metode Penelitian Partisipatoris dan Upaya-upaya Pemberdayaan, Yayasan Obor Indonesia, Jakarta.

Muhadjir, H. Noeng, 2000, Metodologi Penelitian Kualitatif, Rakesarasin, Yogyakarta.

Milles, MB \& Hubberman, AM, (1992) Analisis Data Kualitatif , Terjemahan leh Tjetjep Rohidi dan mulyarto, UI Percetakan, Jakarta.

Riyadi dan Bratakusumah, D.S, 2004, Perencanaan Pembangunan Daerah, PT. Gramedia Pustaka Utama, Jakarta.

Siagian, Sondang P, 1994, Administrasi Pembangunan, Gunung Agung, Jakarta. Singarimbun, Masri dan sofyan Effendi, 1989, Metode
Penelitian Survey, Suntingan LP3ES, Jakarta.

Sugiyono, Memahami Penelitian Kualitatif, Jakarta.

Tjokroamidjojo, Bintoro, 1995, manajemen Pembangunan,

Gunung Agung, Jakarta.

Undang-undang No. 25 Tahun 2004 tentang Sistem perencanaan pembangunan Nasional.

Undang-undang No. 32 Tahun 2004 Tentang Otonomi Daerah

Peraturan Pemerintah Nomor 43 tahun 2014 Tentang Desa 